\title{
Years of life lost due to viral hepatitis in Poland, 2000-2014
}

\author{
Paulina Paciej-Gołębiowska ${ }^{1, C-D \oplus}$, Małgorzata Pikala ${ }^{1, A-C \oplus}$, Irena Maniecka-Bryła ${ }^{1, A, E-F} \oplus$ \\ ${ }^{1}$ Department of Epidemiology and Biostatistics, Medical University, Łódż, Poland \\ A - Research concept and design, B - Collection and/or assembly of data, C - Data analysis and interpretation, \\ $D$ - Writing the article, $E$ - Critical revision of the article, $F$ - Final approval of article \\ Paciej-Gołębiowska P, Pikala M, Maniecka-Bryła I. Years of life lost due to viral hepatitis in Poland, 2000-2014. Ann Agric Environ Med. 2021; \\ 28(2): 300-305. doi: 10.26444/aaem/122301
}

\section{Abstract}

Introduction. Viral hepatitis often affects young people; it therefore seems reasonable to analyze the phenomenon of premature mortality due to this reason, using Years of Life Lost (YLLs) measurement.

Objective. The aim of the study was to analyze YLLs due to viral hepatitis in Poland in 2000-2014. For the years 2002 and 2011, socio-economic variables (marital status, level of education, working status, place of residence) were included.

Materials and method. The research material was a database containing information from 5,601,568 death certificates of Polish citizens from 2000-2014. The data on deaths caused by viral hepatitis, i.e. coded as B15-B19 according to the ICD-10, was used for the analysis. The Standard Expected Years of Life Lost measure was used to calculate YLLs. Analysis of time trends was performed with the linear regression method using the joinpoint model.

Results. In the studied period, 3.628 deaths of Polish citizens were caused by viral hepatitis ( $0.06 \%$ of all deaths), which translated to $92,845.70$ YLLs (16.17 years per 100,000 inhabitants). The number of YLLs increased over time $(p<0.05)$, reaching its highest value in the last analyzed year - 22.14 years per 100,000. The YLLs average per one death was 25.59 years. Among the risk group there were individuals living in urban areas, divorced/separated, with lower than secondary education, and economically inactive.

Conclusions. Despite the fact that Poland belongs to a group of countries with low mortality due to viral hepatitis, this disease is a serious social problem as measured with YLLs. The study provides the basis for policymakers to implement more effective methods to prevent premature deaths caused by this disease.

Key words

standard expected years of life lost, premature mortality, viral hepatitis, health inequalities, SEYLL

\section{INTRODUCTION}

Viral hepatitis is one the most prevalent infectious diseases worldwide, and projections of the World Health Organization (WHO) indicate that in the following years the population of patients will continue to grow [1]. According to the Global Burden of Disease (GBD), between 2005 - 2015, the number of people suffering from viral hepatitis increased by $16.7 \%$, including the number of individuals infected with the hepatitis $\mathrm{C}$ virus (HCV) which rose by $18.0 \%$, hepatitis $\mathrm{B}$ virus (HBV) - by $16.7 \%$, hepatitis A virus (HAV) - by $4.2 \%$, and hepatitis E virus (HEV) - by $3.5 \%$ [2]. Currently, the biggest public health problem are infections caused by HBV and HCV which often have a chronic course (5-10\% of HBV cases and $75-85 \%$ of HCV cases); therefore, they increase the risk of developing liver failure, cirrhosis and hepatocellular carcinoma [3, 4]. It is estimated that in 2015, on a global scale, 257 million people were chronically infected with $\mathrm{HBV}$, while chronic HCV infection affected 71 million people; moreover, only about $10.5 \%$ of those infected with HBV and $19 \%$ of infected with HCV were aware of their infection status [5].

However, the mortality rates due to viral hepatitis, especially among European Union countries, are relatively low. According to Eurostat, in 2014, the highest standardized death rate (SDR) values were found in Italy $(4.02$ per 100,000$)$, Austria (3.16 per 100,000) and Latvia (2.26 per 10,000). Instead, SDRs for chronic liver diseases were highest in Romania

Address for correspondence: Paulina Paciej-Gołębiowska, Department of Epidemiology and Biostatistics, Medical University, Łódż, Poland

E-mail: paulina.paciej@gmail.com

Received: 08.02.2020; accepted: 11.05.2020; first published: 26.05 .2020
(47.77 per 100,000) and Hungary (32.36 per 100,000), and Italy was among the countries with the lowest death rate $(8.81$ per 100,000) [6]. It seems that the availability of detailed data on the causes of deaths, including results of additional tests (ex. microbiological tests), may differ significantly between countries, which leads to an underestimation of mortality rates due to this cause.

Viral hepatitis often affects young people; it therefore seems reasonable to analyze the phenomenon of premature mortality caused by this disease. The simultaneous inclusion of socio-economic variables, which are known to constitute a relevant cause of excess mortality, gives an opportunity to identify the characteristics of a risk group for which preventive activities should be intensified [7, 8, 9].

Recently, the Years of Life Lost (YLLs) measure used for the analysis of premature mortality has attracted special attention. It takes into account not only the number of deaths resulting from a given cause, but also the age of individuals at the time of death. From the economic point of view, it is advisable to focus public health activities on diseases that cause the greatest loss of life potential in a population, based on calculation of the number of YLLs [10].

\section{OBJECTIVES}

The aim of the study was to analyze YLLs due to viral hepatitis in Poland in the years 2000-2014. For the years 2002 and 2011, socio-economic variables (marital status, level of education, working status, place of residence) were included. 


\section{MATERIAL AND METHODS}

The research material was a database containing information collected from 5,601,568 death certificates of Polish citizens from the years 2000-2014, provided by the Central Statistical Office in Poland. The data on deaths caused by viral hepatitis, i.e. covered by codes B15-B19 according to the International Classification of Diseases and Related Health Problems $-10^{\text {th }}$ Revision (ICD-10), was used for the analysis. It included the following:

- B15 - acute hepatitis A

- B16 - acute hepatitis B

- B17 - other acute viral hepatitis

- B18 - chronic viral hepatitis

- B19 - unspecified other viral hepatitis

Mortality rates were calculated based on information on the size of the population provided by the Local Data Bank [11]. The standardization of indicators according to age was carried out using the direct method, taking into account the European population (updated in 2013) as the point of reference.

To assess YLLs, the Standard Expected Years of Life Lost (SEYLL) measure was used, and its value was calculated based on the Murray and Lopez method [10]:

where:

$$
\text { SEYLL }=\sum_{x=0}^{\mathrm{I}} \mathrm{d}_{x} \mathrm{e}_{x}^{*}
$$

$\mathrm{e}^{*} \chi$ - is the average life expectancy for a given age, determined on the basis of a standard population;

$\mathrm{d} \chi$ - the number of deaths at the age of $\chi$;

$\chi$ - age at death;

$\mathrm{I}$ - the oldest age in a given population.

The SEYLL per Person (SEYLL ) meter was also used. This is the ratio of SEYLL to the size of the population, and in this study, it was calculated per 100,000 inhabitants.

SEYLL per Death $\left(\right.$ SEYLL $\left._{\mathrm{d}}\right)$, which determines the number of YLLs per one death, was calculated by dividing SEYLL by the number of deaths due to a given cause.

The above-mentioned measures were based on a life expectancy table published by the WHO in 2012, according to which the expected survival for both genders at the age of 0 is 86.02 years [12].

The analysis of time trends was performed with the linear regression method using the joinpoint model, with the application of the Joinpoint Regression Program [13]. Annual percentage changes (APC) in separate time intervals with the corresponding 95\% confidence intervals (CI) were calculated for SDR and for SEYLL.

Additionally, for the years 2002 and 2011, YLLs were assessed according to marital status, level of education, working status and place of residence. These years were considered since at that time the last two censuses of the Polish population were taken, and they provided information on the size of the population in particular socio-economic groups $[14,15]$. Data from the censuses were limited to the population aged 15 or over; therefore, the SEYLL values according to the mentioned variables refer to the population at this age. It should be emphasized that in 2002 and 2011 no deaths caused by viral hepatitis were found in the group of people under 15 years of age.
Area codes identifying places of residence were assigned to two variants:

- urban area;

- rural area.

Marital status was classified into four categories:

- single;

- married;

- divorced / separated;

- widowed.

Three levels of education were distinguished in accordance with the International Standard Classification of Education [16]:

- less than secondary education (levels 0-2);

- secondary education (levels 3-4);

- university education (levels 5-8).

On the basis of the working status, the following groups were distinguished:

- economically active (working or receiving unemployment benefits);

- economically inactive (using a non-commercial source of income or dependent on another person).

It should be emphasized that one death certificate from 2002 and three death certificates from 2011 lacked data on the employment status. Data on all the other variables were complete.

For each socioeconomic variable, the rate ratio (RR) was calculated as the quotient of SEYLL in the less privileged group to $S E Y L L_{p}$ in the more privileged group, with the $95 \%$ CI [17].

\section{RESULTS}

In the analyzed years, 3,628 deaths of Polish citizens caused by viral hepatitis were found ( $0.06 \%$ of all deaths) - 2,112 deaths were recorded in men (58.21\%), and 1,516 deaths in women (41.79\%). For this reason, throughout the studied period, the $\mathrm{SDR}$ remained on an almost unchanged level $(\mathrm{APC}=-0.5$; 95\% CI: $-1.6,0.7 ; \mathrm{p}=\mathrm{ns}$ ), reaching the value of 0.89 per 100,000 inhabitants in 2000 and 0.93 per 100,000 in $2014-1.29$ and 1.18 per 100,000 men $(A P C=-0.9 ; 95 \% C I:-3.6,2.0 ; \mathrm{p}=n s$ ), 0.63 and 0.72 per 100,000 women $(\mathrm{APC}=0.7 ; 95 \% \mathrm{CI}:-1.1$, 2.6; $\mathrm{p}=\mathrm{ns})$, respectively. It is worth noting that in the initial period, i.e. between 2000 - 2011, in the group of men, there was a statistically significant downward trend in SDR $(\mathrm{APC}=-3.5$; 95\% CI: -5.2, -1.7; $\mathrm{p}<0.05)$; however, at a later stage (2011-2014), it was reversed $(\mathrm{APC}=9.3 ; 95 \% \mathrm{CI}:-4.5,25.0 ; \mathrm{p}=\mathrm{ns})$.

In the analyzed years, viral hepatitis caused 92,845.70 YLLs in total - 58,552.63 years in men (63.06\%) and 34,293.07 years in women (36.94\%). During this time, SEYLL for the general population showed an upward trend (APC $=1.9 ; 95 \%$ CI: $0.8,3.2 ; \mathrm{p}<0.05)$, reaching its highest value in the last year of the study -22.14 years per 100,000 people. Similarly, SEYLL values increased over time in both genders (for men: $\mathrm{APC}=2.0 ; 95 \% \mathrm{CI}: 0.8,3.2 ; \mathrm{p}<0.05$, for women: $\mathrm{APC}=2.0 ; 95 \%$ CI: $-0.1,4.2 ; \mathrm{p}=\mathrm{ns}$ ), and were highest in $2014-28.72$ years per 100,000 men and 15.97 years per 100,000 women. The average value of SEYLL for the entire examined period was 16.17 years per 100,000 people -21.07 years per 100,000 men and 


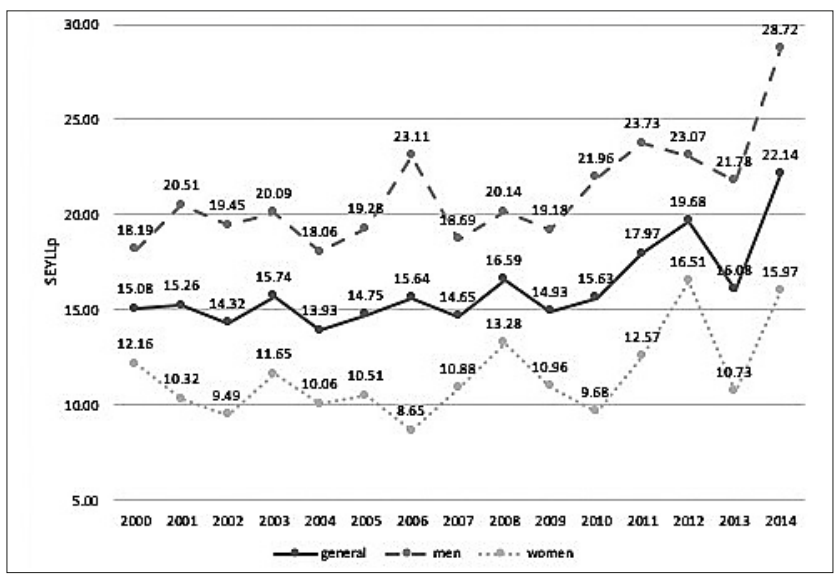

Figure 1. Years of Life Lost due to viral hepatitis in Poland in 2000-2014 by gender (per 100,000)

11.57 years per 100,000 women (Fig. 1). The average number

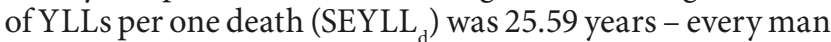
who died due to viral hepatitis in the studied time lost 27.72 years, whereas every woman lost 22.62 years.

The highest number of deaths in the discussed group of diseases was due to chronic viral hepatitis (B18) - it was the cause of 3,015 deaths (83.10\%), which translated to 77,226.43 YLLs (83.18\%). Acute hepatitis B (B16) was the cause of 365 deaths (10.6\%) and 9,084.80 YLLs (9.78\%), other acute viral hepatitis (B17) - 129 deaths (3.56\%) and 3,571.93 YLLs (3.85\%), unspecified other viral hepatitis (B19) - 115 deaths (3.17\%) and 2,810.59 YLLs (3.03\%), and acute hepatitis A (B15) - 4 deaths (0.11\%) and 151.95 YLLs (0.16\%).

Attention is drawn to the changing percentage rates of deaths due to particular diseases over the analyzed years. At the beginning of the study period, chronic viral hepatitis (B18) was the cause of $53.25 \%$ deaths, while in the last year of the study it was already the cause of $93.75 \%$ deaths. For this reason, also SEYLL showed an upward trend $(\mathrm{APC}=5.3$; $95 \%$ CI: $4.2,6.5 ; \mathrm{p}<0.05)$. The described changes over time co-occurred with a decrease in the percentage rate of deaths triggered by other causes, especially by acute hepatitis B (B16) - the percentage of deaths due to this disease dropped from $31.17 \%$ in 2000 to $2.19 \%$ in 2014 , and also SEYLL showed a downward trend in the analyzed period (APC $=-14.9 ; 95 \% \mathrm{CI}$ : $-18.8,-10.8 ; \mathrm{p}<0.05)$. Analogous tendencies were observed in both genders [Tab. 1].

The socio-economic characteristics of deaths due to viral hepatitis in Polish citizens aged 15 years and above in 2002 and 2011 are presented in the Supplementary Table.

YLLs according to place of residence. Both in men and

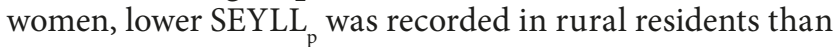

in people living in urban areas. SEYLL for men living in rural areas reached the value of 4.93 years in 2002, and increased to 7.23 years in 2011, and in urban inhabitants it was 25.63 and 34.72 years, respectively. RR in urban residents was 2.56 in 2002 and increased to 3.47 in 2011. In women, SEYLL ${ }_{\mathrm{p}}$ among rural inhabitants amounted to 7.86 years in $2002^{\mathrm{p}}$ and 5.84 years in 2011, while in urban ones it was 13.45 and 19.07 years - this translated into an increase in RR in this group from 1.71 to 3.26 , respectively [Fig. 2, Tab. 2].

YLLs according to marital status. In both analyzed years, in men the smallest SEYLL palues were observed in those who were single (17.74 years in 2002 and 19.42 years in 2011). In 2002, the highest SEYLL ${ }_{\mathrm{p}}$ was recorded in widowed men (54.73 years with a decrease to 28.97 years in 2011), and in 2011, in divorced/separated men (77.77 years, with the value of 47.59 years in 2002). RR in the group of widowed men dropped from 3.09 in 2002 to 1.49 in 2011, and in divorced/separated men it rose from 2.68 to 4.00 , respectively. In women, the lowest $S E Y L_{p}$ was also observed among those who were single (3.63 in 2002 and 5.27 in 2011), whereas the highest among widows (28.39 in 2002 and 26.44 in 2011), and among divorced/separated individuals (27.23 in 2002 and 36.54 in 2011). RR in widows dropped from 7.83 to 5.02 and in divorced/separated persons from 7.51 to 6.94 .

YLLs according to level of education. Analysis of YLLs according to the educational level revealed the lowest SEYLL values in men with university education (14.60 years in 2002 and 16.30 years in 2011), and higher values in men with less than secondary (24.40 years in 2002 and 33.43 years in 2011) and secondary education (24.35 and 32.12 years, respectively). RR for men with less than secondary education was 1.67 in 2002 and increased to 2.05 in 2011, and for men with secondary education it increased from 1.67 to 1.97 , respectively. In women, SEYLL was also the lowest in the group with higher education (1.98 years in 2002 and 8.92 years in 2011). In 2002, the highest SEYLL values were recorded in women with less than secondary education (16.51 years with a decrease to 15.97 years in 2011), while in 2011 in women with secondary education (18.17 years, and 10.33 years in 2002). RR in women with less than secondary education dropped from 8.32 in 2002 to 1.79 in 2011 , and in women with secondary education from 5.21 to 2.04 , respectively.

YLLs according to working status. Being economically active was associated with a smaller loss of years of life than being economically inactive. SEYLL ${ }_{p}$ among economically

Table 1. Time trends of Years of Life Lost due to viral hepatitis in Poland in 2000-2014 by cause, according to ICD-10

\begin{tabular}{|c|c|c|c|}
\hline \multirow{2}{*}{ Causes of death } & Men & Women & Total \\
\hline & $A P C(95 \% C I)$ & $A P C(95 \% C l)$ & $A P C(95 \% C l)$ \\
\hline Acute hepatitis B (B16) & $-13.3^{*}(-17.5 ;-9.0)$ & $-18.4^{*}(-24.5 ;-11.9)$ & $-14.9 *(-18.8 ;-10.8)$ \\
\hline Other acute viral hepatitis (B17) & $-16.0(-32.3 ; 4.3)$ & $-5.9(-15.6 ; 5.0)$ & $-6.3(-12.8 ; 0.8)$ \\
\hline Chronic viral hepatitis (B18) & $5.6^{*}(3.9 ; 7.3)$ & $4.9 *(3.1 ; 6.8)$ & $5.3^{*}(4.2 ; 6.5)$ \\
\hline Unspecified other viral hepatitis (B19) & $-18.3(-34.1 ; 1.3)$ & $-16.8(-30.9 ; 0.4)$ & $-15.4^{*}(-24.8 ;-4.8)$ \\
\hline
\end{tabular}

APC - Annual Percentage Change; Cl - Confidence Interval; * $p<0.05$ 


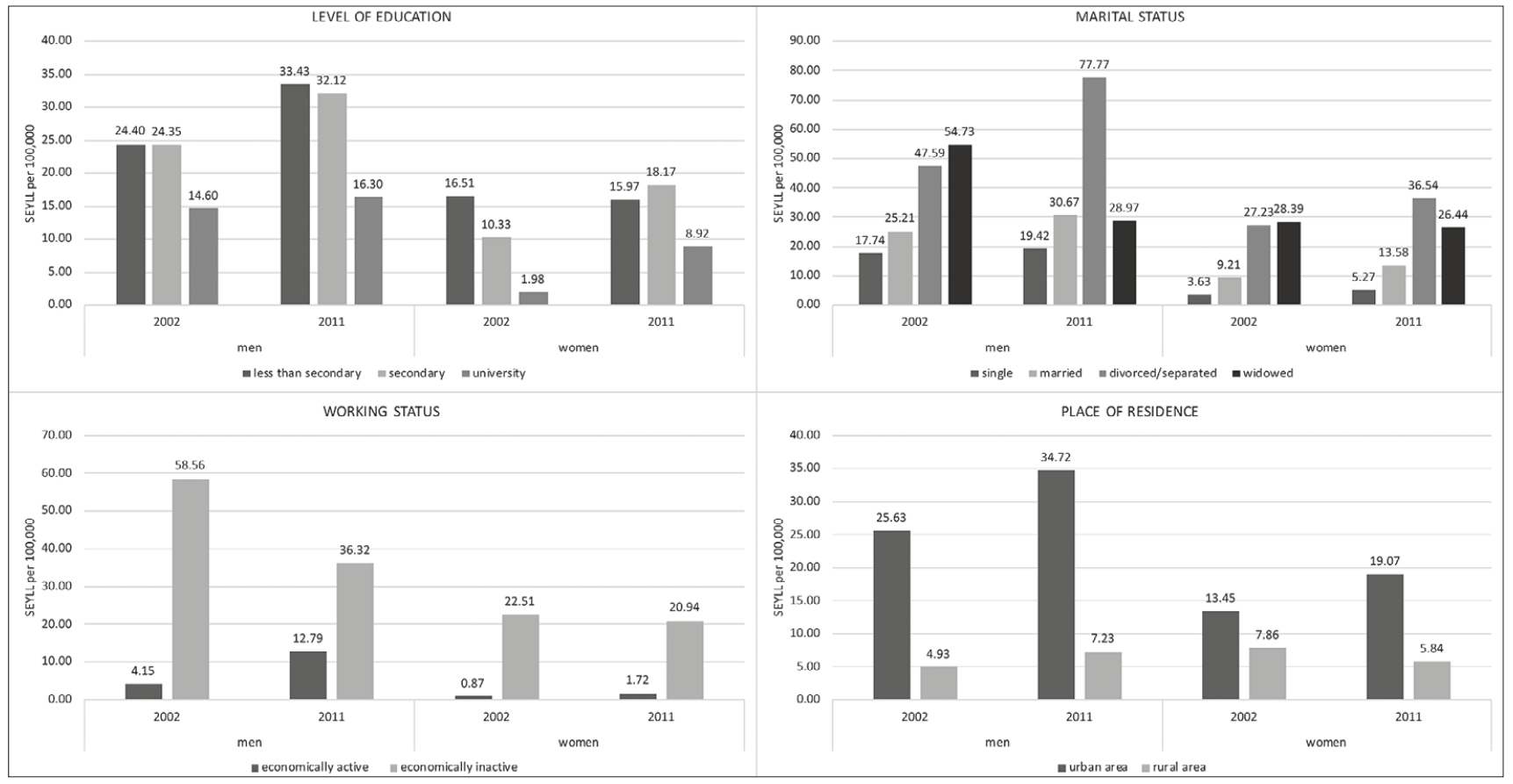

Figure 2. Years of Life Lost due to viral hepatitis among inhabitants of Poland aged 15 years and over in 2002 and 2011 , according to socio-economic factors.

Table 2. Socio-economic inequalities in Years of Life Lost due to viral hepatitis in Poland, 2002 and 2011, by gender

\begin{tabular}{|c|c|c|c|c|}
\hline & \multicolumn{4}{|c|}{ Rate ratio [95\% confidential intervals] } \\
\hline & \multicolumn{2}{|c|}{ Men } & \multicolumn{2}{|c|}{ Women } \\
\hline & 2002 & 2011 & 2002 & 2011 \\
\hline \multicolumn{5}{|l|}{ Level of education } \\
\hline Less than secondary education & $1.67[1.46 ; 1.92]$ & $2.05[1.84 ; 2.29]$ & $8.32[6.27 ; 11.05]$ & $1.79[1.58 ; 2.04]$ \\
\hline Secondary education & $1.67[1.46 ; 1.90]$ & $1.97[1.78 ; 2.18]$ & $5.21[3.92 ; 6.93]$ & $2.04[1.82 ; 2.29]$ \\
\hline University education & 1.00 & 1.00 & 1.00 & 1.00 \\
\hline \multicolumn{5}{|l|}{ Marital status } \\
\hline Single & 1.00 & 1.00 & 1.00 & 1.00 \\
\hline Married & $1.42[1.31 ; 1.54]$ & $1.58[1.47 ; 1.70]$ & $2.54[2.13 ; 3.03]$ & $2.58[2.23 ; 2.98]$ \\
\hline Divorced/separated & $2.68[2.31 ; 3.11]$ & $4.00[3.60 ; 4.46]$ & $7.51[6.04 ; 9.33]$ & $6.94[5.85 ; 8.23]$ \\
\hline Widowed & $3.09[2.67 ; 3.56]$ & $1.49[1.25 ; 1.78]$ & $7.83[6.54 ; 9.37]$ & $5.02[4.30 ; 5.85]$ \\
\hline \multicolumn{5}{|l|}{ Working status } \\
\hline Economically active & 1.00 & 1.00 & 1.00 & 1.00 \\
\hline Economically inactive & $14.12[4.59 ; 5.88]$ & $2.84[2.66 ; 3.03]$ & $25.90[20.31 ; 33.01]$ & $12.15[10.23 ; 14.42]$ \\
\hline \multicolumn{5}{|l|}{ Place of residence } \\
\hline Urban area & $5.20[4.59 ; 5.88]$ & $4.80[4.35 ; 5.30]$ & $1.71[1.54 ; 1.90]$ & $3.26[2.92 ; 3.64]$ \\
\hline Rural area & 1.00 & 1.00 & 1.00 & 1.00 \\
\hline
\end{tabular}

active men amounted to 4.15 years in 2002 and 12.79 years in 2011, while among inactive men it was 58.56 and 36.32 years, respectively. RR in this group decreased from 14.12 in 2002 to 2.84 in 2011. In women, SEYLL among economically active persons amounted to 4.80 years in 2002 and 15.29 years in 2011, while in inactive individuals it was 39.81 and 27.41 years, respectively. RR in this group decreased from 8.29 in 2002 to 1.79 in 2011.

\section{DISCUSSION}

The predominant causes of mortality in the Polish population, as in other developed countries, are cardiovascular diseases and malignant tumours $[18,19]$. For many years, infectious diseases have constituted a small percentage of deaths, not exceeding 1\% [20].

Viral hepatitis causes about $0.06 \%$ of deaths among Polish citizens annually. In 2000-2014, the mortality rate caused by this disease was 0.93 per 100,000 people, which was lower than the average for EU countries - in 2014 it was 1.40 per 100,000 [6]. The results of the current study confirm that viral hepatitis is a social problem also in countries with low mortality caused by this factor. It was revealed that in Poland in 2000-2014, mortality due to this cause remained at a low, almost unchanged level, but the number of YLLs for this reason was still increasing $(\mathrm{p}<0.05)$, with the highest value observed in the last analyzed year. 
Attention is also paid to the increasing share of YLLs due to chronic viral hepatitis, with its decline from other causes, especially acute hepatitis B. Transmission routes of $\mathrm{HBV}$ and $\mathrm{HCV}$ infection are convergent - this suggests the high effectiveness of the anti-HBV vaccination programme in the Polish population, with a definitely unsatisfactory level of other preventive methods. Epidemiological data indicate that HCV infection in Poland is most often caused by medical procedures - this transmission path was found in $67-75 \%$ of cases of infections recorded in $2000-2012$. This is an extremely alarming situation. It is estimated that, on average in the EU countries, medical procedures are the cause of only $4 \%$ of cases, while about $75 \%$ of them occur through intravenous drug injections $[21,22]$. In the Polish population, infections triggered this way occur in $6-7.5 \%$ of cases [23].

Analysis of the YLLs due to viral hepatitis according to socio-economic variables has shown that the risk group are people living in urban areas, divorced/separated, with lower than secondary education and economically inactive. Moreover, observation of SEYLL changes over time revealed that the most unfavourable situation is among divorced men with lower than secondary education and is constantly deteriorating. It is possible that in this group insufficient knowledge on the routes of the infection transmission and its oligosymptomatic course results in delayed diagnostics. Apart from that, lack of awareness of the disease complications may be associated with a poorer compliance during treatment. It is also likely that in these patients, additional risk factors affect a worse course of infection. The authors' own study results indicate that the characteristics of a group of people particularly exposed to premature loss of life due to chronic liver diseases, in particular alcohol-related diseases, are similar to that presented above for viral hepatitis [24]. Finally, it should be taken into account that a low socioeconomic status is a significant risk factor for increased general mortality $[25,26]$.

Apart from an inefficient primary prophylaxis, the problem in the Polish population is also the difficult access to effective treatment of viral hepatitis, especially to directacting antivirals (DAA) [27]. It is recommended that all individuals chronically infected with $\mathrm{HCV}$, regardless of the severity of the disease, should receive treatment, but in Poland, currently mainly people with advanced liver fibrosis are administered DAA [28].

All these aspects are reflected in the extremely high SEYLL index due to viral hepatitis in Poland. Its average value in 2000-2014 was 25.59 years - 27.72 years in men and 22.62 years in women. In comparison, in 2014, SEYLL due to malignant neoplasms of the digestive system in the Polish population was 20.0 years in men and 17.1 years in women [29]; due to ischemic heart diseases - 18.3 years and 11.3 years, due to cerebrovascular diseases -17.3 years and 11.5 years [30], due to bladder cancer - 17.0 years and 15.7 years [31], respectively.

Limitations. The limitations of the study are mainly imposed by the use of a dataset based on death certificates as a research material. Firstly, the design of the certificate does not take into account comorbidities, which could result in the omission of many deaths where viral hepatitis had a significant role. Secondly, identifying an infectious disease as a cause of death does not imply the necessity of including in the card information on a particular infectious agent responsible for the development of the disease and, consequently, death. Thirdly, some errors might appear while determining the causes of death and matching the codes according to the ICD-10.

\section{CONCLUSIONS}

Despite the fact that Poland is a country with low mortality due to viral hepatitis, this disease is a serious social problem as measured with YLLs. In the study period, the mortality rate was almost unchanged, but SEYLL showed an upward trend $(\mathrm{p}<0.05)$, reaching its highest value in the last analyzed year. The increasing share of YLLs due to chronic viral hepatitis, with its decline from other causes, especially acute hepatitis $\mathrm{B}$, is of a concern.

Efforts should be made to provide effective treatment to a greater number of patients, but it is also essential to intensify prevention methods. These, as indicated in the study, should be primarily addressed to people living in urban areas, divorced/separated, with lower than secondary education, and economically inactive.

\section{REFERENCES}

1. World Health Organization. Global Health Sector Strategy on Viral Hepatitis, 2016-2021. Geneva, Switzerland 2016. Available from: http://apps.who.int/iris/bitstream/handle/10665/246177/WHO-HIV2016.06-eng.pdf;jsessionid=7C0A3A82F2D066A73C7691BA668420F 2? sequence $=1$ (access: 2019.11.03).

2. Vis T, Allen C, Arora M, Barber RM, Bhutta Za, Brown A, et al. Global, regional, and national incidence, prevalence, and years lived with disability for 310 diseases and injuries, 1990-2015: a systematic analysis for the Global Burden of Disease Study 2015. Lancet. 2016; 388: 1545-1602.

3. Shepard CW, Simard EP, Finelli L, Flore AE, Bell BP. Hepatitis B virus infection: epidemiology and vaccination. Epidemiol Rev. 2006; 28: $112-125$.

4. Ansaldi F, Orsi A, Sticchi L, Bruzzone B, Icardi G. Hepatitis C virus in the new era: Perspectives in epidemiology, prevention, diagnostics and predictors of response to therapy. World J Gastroenerol. 2014; 20(29): 9633-9652.

5. World Health Organization. Global Hepatitis Report, 2017. Geneva, Switzerland 2017. Available from: http://apps.who.int/iris/bitstream/ handle/10665/255016/9789241565455-eng.pdf?sequence $=1$ (access: 2019.11.03)

6. Eurostat database. Available from: https://ec.europa.eu/eurostat/data/ database (access: 2019.11.03).

7. Whitehead M, Dahlgren G. Concepts and principles for tackling social inequities in health: levelling up, part 1. Copenhagen, WHO Regional Office for Europe, 2007. Available from: http://www.euro.who.int/_data/assets/pdf_file/0010/74737/E89383.pdf (access: 2019.10.23).

8. Pikala M, Maniecka-Bryła I. Socioeconomic inequalities in mortality due to all causes in the working age population of Poland in 2002 and 2011. Med Pr. 2017; 68(6): 771-778.

9. Bryła M, Maniecka-Bryła I, Burzyńska M, Pikala M. Years of life lost of inhabitants of rural areas in Poland due to premature mortality caused by external reasons of death 1999-2012. Ann Agric Environ Med. 2016; 23(4): 598-603.

10. Murray CJL, Lopez AD. The Global Burden of Disease. A comprehensive assessment of mortality and disability from diseases, injuries and risk factors in 1990 and projected to 2010. Boston: Harvard University Press, 1996.

11. Central Statistical Office in Poland. Local Data Bank. Available from: http://www.bdl.stat.gov.pl (access: 2019.10.28).

12. Murray CJL, Ezzati M, Flaxman AD, Lim S, Lozano R, Michaud C, et al. GBD 2010: design, definitions, and metrics. Lancet. 2012; 380: 2063-2066.

13. National Cancer Institute, Surveillance Research Program, Statistical Methodology and Applications Branch. Joinpoint Regression Program, Version 4.2.0-April 2015. 
14. European Statistical System. Available from: https://ec.europa.eu/ CensusHub2/query.do?step=selectHyperCube\&qhc=false (access: 2019.11.23).

15. Central Statistical Office in Poland. National Census 2002. Available from: http://stat.gov.pl/spisy-powszechne/narodowe-spisypowszechne/narodowy-spis-powszechny-2002/ (access: 2019.10.23).

16. International Standard Classification of Education 2011. Montreal, UNESCO Institute for Statistics, 2012. Available from: http://uis. unesco.org/sites/default/files/documents/international-standardclassification-of-education-isced-2011-en.pdf (access: 2019.10.24).

17. Mackenbach JP, Kunst AE. Measuring the magnitude of socio-economic inequalities in health: An overview of available measures illustrated with two examples from Europe. Soc Sci Med. 1997; 44(6): 757-771.

18. Maniecka-Bryła I, Pikala M, Bryła M. Life years lost due to cardiovascular diseases. Kardiol Pol. 2013; 71: 1065-1072.

19. Pikala M, Maniecka-Bryła I. Years of life lost due to malignant neoplasms characterized by the highest mortality rate. Arch Med Sci. 2014; 10(5): 999-1006.

20. Bryła M, Dziankowska-Zaborszczyk E, Bryła P, Pikala M, ManieckaBryła I. Years of life lost due to infectious diseases in Poland. PLoS ONE. 2017; 12(3): e0174391.

21. European Centre for Disease Prevention and Control. Hepatitis B and C surveillance in Europe 2012. Stockholm: ECDC, 2014.

22. Chlabicz S, Flisiak R, Grzeszczuk A, Kovalchuk O, Prokopowicz D, Chyczewski L. Known and probable risk factors for hepatitis C infection: a case series in north-eastern Poland. World J Gastroenterol. 2006; 12: 141-145.
23. Stępień M, Rosińska M. Hepatitis C outbreaks in Poland in 2003-2013. Medical procedures as a dominant route of HCV transmission. Przegl Epidemiol. 2015; 69: 465-472.

24. Paciej-Gołębiowska P, Pikala M, Maniecka-Bryła I. Years of life lost due to diseases of the digestive system in Poland according to socioeconomic factors: a cross-sectional study. BMJ Open. 2019; 9: e030304.

25. Mackenbach JP, Stirbu I, Roskam AJ, Schaap MM, Menvielle G, Leinsalu $\mathrm{M}$, et al. Socioeconomic inequalities in health in 22 European countries. N Engl J Med. 2008; 358(23): 2468-2481.

26. Huisman M, Kunst AE, Bopp M, Borgan JK, Borrell C, Costa G, et al. Educational inequalities in cause-specific mortality in middle-aged and older men and women in eight western European populations. Lancet. 2005; 365(9458): 493-500.

27. Zieliński A, Rosińska M. The problem of elimination of HCV infections in Poland. Przegl Epidemiol. 2017; 71(1): 3-14.

28. European Association of the Study of the Liver. EASL Recommendations on Treatment of Hepatitis C 2016. J Hepatol 2016.

29. Paciej-Gołębiowska P, Pikala M, Maniecka-Bryła I. Years of life lost due to malignant neoplasms of the digestive system in Poland in the years 2000-2014. United European Gastroenterol J. 2018; 6(6): 943-951.

30. Pikala M, Maniecka-Bryła I. Fifteen-year mortality trends due to cardiovascular diseases in Poland using standard expected years of life lost, 2000-2014. Kardiol Pol. 2017; 75(10): 1030-1040.

31. Jobczyk M, Pikala M, Różański W, Maniecka-Bryła I. Years of life lost due to bladder cancer among the inhabitants of Poland in the years 2000 to 2014. Cent European J Urol. 2017; 70(4): 338-343. 